\title{
BILJNI UREĐAJI ZA PROČIŠĆAVANJE OTPADNIH VODA
}

\author{
Marija Šperac \\ Sveučilište Josipa Jurja Strossmayera u Osijeku, Građevinski fakultet Osijek, docent \\ Jelena Kaluđer \\ Sveučilište Josipa Jurja Strossmayera u Osijeku, Građevinski fakultet Osijek, univ.bacc.ing.aedif. \\ Željko Šreng \\ Sveučilište Josipa Jurja Strossmayera u Osijeku, Građevinski fakultet Osijek, mag.ing.aedif.
}

Sažetak: Otpadne vode se moraju pročistiti prije ispuštanja u recipijent. Jedan od načina pročišćavanja otpadnih voda je pročišćavanje biljnim uređajima. Biljni uređaji su kompleksni biološki sustavi koji oponašaju procese u prirodi. Jednostavan su, prihvatljiv i ekonomski opravdan način zaštite voda. U radu su opisani biljni uređaji (umjetne močvare) kroz vrste uređaja, njihove prednosti i nedostatke, osnove projektiranja i hidraulički proračun. Posebno je analiziran biljni uređaj Vinogradci.

Ključne riječi: otpadne vode, pročišćavanje, biljni uređaji, okoliš

\section{CONSTRUCTED WETLANDS FOR WASTEWATER TREATMENT}

\begin{abstract}
Waste water must be treated prior to discharge into the recipient. One way of treating waste water is constructed wetland for wastewater treatment. Constructed wetlands are complex biological systems that mimic the processes in nature. These systems are simple, acceptable and economically feasible way of water protection. This paper describes the constructed wetlands through device types, their advantages and disadvantages, the basics of design and hydraulics. Especially analyzed constructed wetland Vinogradci.
\end{abstract}

Keywords: waste water treatment, constructed wetland, environment 


\section{Uvod}

Posljedica razvoja naselja i povećanje standarda življenja je zagađenje okoliša, a jedan od značajnih elemenata zagađenja je zagađenje voda. Povećanom potrošnjom vode raste i količina otpadnih voda. Odvodnja i ispuštanje otpadnih voda u recipijente u pojedinim područjima je različito riješeno, u većini slučajeva nedovoljno $\mathrm{i}$ neadekvatno. Otpadne vode se često bez pročišćavanja upuštaju u prirodne recipijente: vodotoke, jezera, mora i tlo. Potrebno je pristupiti izgradnji integralnog sustava odvodnje i pročišćavanja otpadnih i zagađenih voda što je nužan korak prema očuvanju zdravog okoliša i jedan od osnovnih preduvjeta održivog razvoja. Prije ispuštanja otpadnih voda u prirodne prijemnike ili recipijente, iste se moraju prethodno pročistiti u konvencionalnim ili nekonvencionalnim uređajima za pročišćavanje otpadnih voda.

U naseljima do 5000 stanovnika i bez značajno razvijene industrije izgradnja konvencionalnih uređaja za pročišćavanje otpadnih voda skupa je i neprihvatljiva.Prihvatljivije je rješenje izgradnja uređaja koji koriste prirodne procese pročišćavanja otpadnih voda, te da se pročišćena voda može koristiti za potrebe natapanja poljoprivrednih površina [1]. Uređaji za pročišćavanje u prirodnim uvjetima su polja za natapanje, podzemna filtracija, lagune, oksidacijski kanali i umjetne močvare ili biljni uređaji [2].

\section{Biljni uređaj za pročišćavanje otpadnih voda}

Rast svijesti o nužnosti skrbi za očuvanje okoliša uzrokovao je razvoj tehnologije obrade otpadnih voda u skladu $\mathrm{s}$ rastućim brojem zakona o zaštiti okoliša. Zahtjevi za obradu otpadnih voda uključuju mogućnost ponovne upotrebe iste $u$ industriji ili u poljoprivredi za navodnavanje poljoprivrednih površina. Biljni uređaji za pročišćavanje otpadnih voda su prirodna alternativa konvencionalnim tehničkim metodama za pročišćavanje otpadnih voda [3]. Prirodni procesi pročišćavanja voda oduvijek su se odvijali u rijekama, jezerima, vodotocima i močvarama, a ekosustavi u kojima dominiraju vodene biljke najproduktivniji su. Visoka produktivnost rezultat je velikih aktivnosti mikroorganizama, što ukazuje i na veličinu kapaciteta tih sustava za razgradnju organskih tvari. Koristeći se tim saznanjima godine 1952. na njemačkom institutu Max Planck započela su istraživanja uporabe močvarnih biljaka u sustavu pročišćavanja otpadnih voda izgradnjom umjetne močvare nazvane biljni pročišćivač, a koja je oponašala proces prirodne močvare. Nakon toga u mnogim zemljama Europe i Amerike nastavila su se istraživanja i eksperimentiranja na biljnim pročišćivačima sve do današnjih dana. Prilikom izgradnje i projektiranja biljnih uređaja projektantima je dana mogućnost utjecaja na odabir supstrata, tip vegetacije i vrstu protoka vode kroz sustav, vodeći računa o tome da se proces pročišćavanja odvija pomoću bioloških, fizikalnih i kemijskih procesa, kao što su sedimentacija, precipitacija, adsorpcija, asimilacija putem biljnih tkiva i transformacija mikroorganizmima [3].

Upotreba biljnih uređaja u porastu je u svjetskim razmjerima. Danska, Njemačka i Velika Britanija imaju preko 200 biljnih uređaja za obradu sanitarnih otpadnih voda, Sjeverna Amerika više od 400 biljnih uređaja za obradu sanitarnih, industrijskih, poljoprivrednih i oborinskih otpadnih voda, Češka posjeduje više od 100 biljnih uređaja za obradu otpadnih voda [4], dok naš najbliži susjed, Slovenija, pozitivno iskustvo korištenja biljnog uređaja za obradu otpadne vode iz prehrambene industrije poznaje još od 1991. godine [5]. Biljni uređaji pročišćavaju sve otpadne vode, a najviše služe za pročišćavanje kućanskih otpadnih voda manjih naselja [6], farmi [7], turističkih naselja, pročišćavanje procjedne vode iz odlagališta otpada [8], za rekultivaciju korita rijeka i kanala te tercijarno pročišćavanje otpadnih voda [9], pročišćavanje otpadnih voda manjih tvornica s organski onečišćenom otpadnom vodom (pročišćavanje otpadnih voda prehrambene i tekstilne industrije [10]) .U Republici Hrvatskoj tek su se u proteklih nekoliko godina intenzivnije počeli realizirati projekti uređaja za obradu otpadnih voda različitih vrsta. Biljni uređaji, unatoč velikoj primjeni u Europi, u Republici Hrvatskoj još uvijek se malo primjenjuju [11]. Veći biljni uređaji u Hrvatskoj su: Vinogradci, Hruščica, Žminj u Istri, autokamp Glavotok na Krku, autokamp Bijar na Cresu, pilot biljni uređaj Jakuševac.

Biljni se uređaji, prema protoku vode kroz uređaj, dijele na: sustav s vertikalnom protokom i sustav $s$ horizontalnom protokom, te na površinski i podpovršinski biljni uređaj. Površinski biljni uređaj je onaj uređaj u kojem je površina vode koja prolazi sustavom izložena atmosferi. Biljni uređaj s površinskim tokom vode sastoji se od plitkog bazena s vodom, tlom ili drugim medijem koji služi za rast ukorijenjenih močvarnih biljaka. Izgleda 
kao prirodna močvara, stanište za brojne biljne i životinjske vrste. Blizu površinskog sloja vode odvijaju se aerobni procesi, dok se u dubljoj vodi i podlozi uglavnom odvijaju anaerobni procesi.

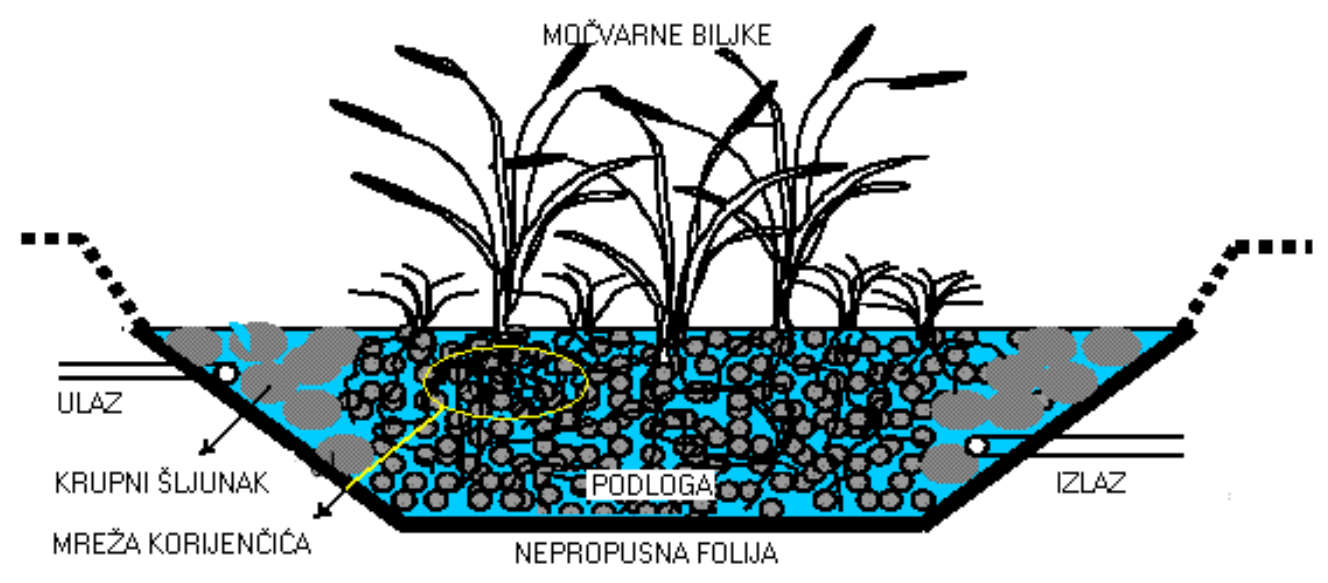

Slika 1 - Klasični podpovršinski biljni uređaj [12]

Kod podpovršinskog uređaja prolaz vode vrši se kroz granulat (kameni materijal ili zemlja) i nije izložen atmosferi. Podpovršinski biljni uređaj sastoji se od jednog ili više međusobno povezanih bazena ukopanih u tlo i obloženih nepropusnom folijom. Bazeni su ispunjeni supstratom od šljunka, pijeska ili nekog sličnog medija kroz koji voda prolazi bez dodira s atmosferom (slika 1). Prednost ovog tipa je neovisnost o klimatskim uvjetima, odsustvo neugodnih mirisa i insekata i vrlo se lijepo uklapa u okoliš kao zasebno formiran ekosustav. Prema načinu protoka vode kroz sustav, podvršinski uređaj može biti horizontalni ili vertikalni.

\subsection{Princip pročišćavanja biološkim uređajem}

Biljni uređaj se sastoji od jednog ili više bazena kroz koje prolazi otpadna voda i ona se na tom putu pomoću bioloških, fizikalnih i kemijskih procesa pročisti. Bazeni se grade s blagim nagibom i s dnom obloženim nepropusnom folijom ili ilovačom. Na takvu se podlogu stavlja supstrat u koji se sade autohtone biljke poput trske, šaša, rogoza i sličnih.

Procesi koji se odvijaju u biljnim uređajima predstavljaju kombinaciju fizikalnih, kemijskih i bioloških procesa. Ti procesi oponašaju prirodu i na taj način obrađuju različite otpadne vode uklanjajući kontaminante. U tablici 1. [12] dan je popis najvažnijih mehanizama uklanjanja.

Tablica 1 - Pregled mehanizama uklanjanja

\begin{tabular}{|c|l|}
\hline tvari sadržane u otpadnoj vodi & \multicolumn{1}{c|}{ mehanizmi uklanjanja } \\
\hline Ukupne suspendirane tvari & Sedimentacija i filtracija \\
\hline Organske tvari (mjerene kao BPK) & Biološka degradacija i sedimentacija \\
\hline Organski zagađivači (npr. pesticidi) & Adsorpcija, isparavanje, fotoliza (biološka i nebiološka degradacija) \\
\hline Dušik & Sedimentacija, nitrifikacija/denitrifikacija, mikrobiološka razgradnja \\
\hline Fosfor & Sedimentacija, filtracija, adsorpcija biljkama i mikroorganizmima \\
\hline Metali & $\begin{array}{l}\text { Sedimentacija, adsorpcija biljkama, mikrobiološki oksidacijsko/ } \\
\text { redukcijski procesi }\end{array}$ \\
\hline Patogeni & $\begin{array}{l}\text { Sedimentacija, filtracija, prirodno odumiranje, UV zračenje, } \\
\text { antibiotsko djelovanje iz korijana biljke }\end{array}$ \\
\hline
\end{tabular}




\subsection{Osnovna načela projektiranja i hidraulički proračun biljnih uređaja}

Pri projektiranju biljnih uređaja za pročišćavanje otpadnih voda potrebno je uzeti u obzir karakteristike otpadnih voda koje će se pročišćavati, kao i potreban stupanj pročišćavanja. Glavne karakteristike otpadnih voda uključuju koncentraciju otopljenih tvari i čvrstih organskih spojeva, tj. biokemijsku potrošnju kisika, sustendirane tvari, spojeve dušika i fosfora, teške metale, patogene bakterije i/ili viruse. Biljni uređaj treba biti projektiran za ukljanjanje tih karakteristika do dozvoljenih ograničenja. Projektiranje uređaja podrazumjeva određivanje hidrauličkog kapaciteta, razine opterećenja, vrijeme zadržavanja (retenciranja), vrste biljaka.Navedeni parametri su definirani propisima i ograničenjima za ispuštanje efluenta. Biljni uređaji su dinamički sustavi podložni različitim utjecajima: od regionalnih klimatskih uvjeta, geoloških karakteristika do lokalne vegetacije [13].

Hidraulički kapacitet može se definirati kao sposobnost biljnog uređaja da pročisti određeni volumen otpadne vode u danom vremenu.Ovo razdoblje se naziva hidrauličko vrijeme retenciranja (HRT), ovisno je 0 veličini zagađenja i zadanoj razini pročišćavanja. Karakteristično vrijeme zadržavanja za uklanjanje BPK je 2-5 dana i 7-14 dana za uklanjanje dušika. HRT se može izračunati po slijedećoj formuli [13]:

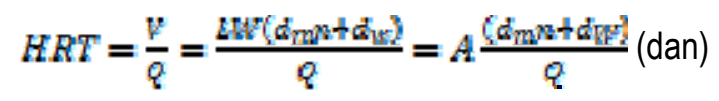

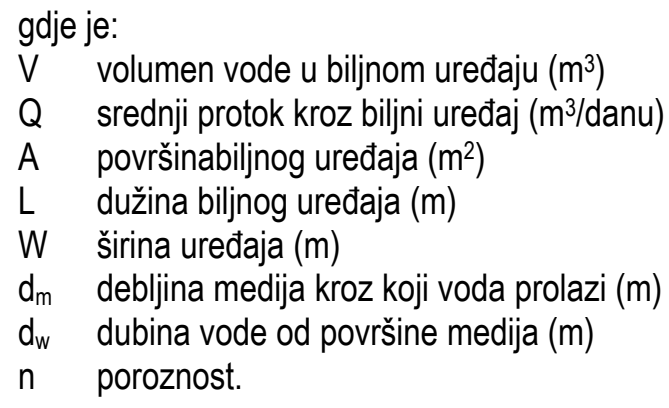

\section{Biljni uređaj za pročišćavanje otpadnih voda Vinogradci}

Prigradsko naselje Vinogradci smješteno je u slivnom području Karašica - Vučica i udaljeno je približno 6 km od grada Belišće, odnosno $5 \mathrm{~km}$ od grada Valpovo. Riječ je 0 ruralnom naselju bez industrijskih proizvodnih pogona. Prema podacima popisa stanovništva iz 1991. godine u naselju je živjelo 282 stanovnika. Kako je naselje izvan državne ceste D34 Daruvar - Slatina - Donji Miholjac - Josipovac i udaljeno 6, odnosno $5 \mathrm{~km}$ od najbližih gradskih središta Belišće i Valpovo, te u njemu nema industrijskih pogona, ne očekuje se značajno povećanje broja stanovnika. Naselje pripada izrazito ravničarskom kraju i nalazi se u središnjem nizinskom dijelu slivnog područja Karašica - Vučica. U samom naselju nekoliko je melioracijskih kanala, ali nema niti jednog većeg vodotoka. U naselju je devedesetih godina prošlog stoljeća sproveden vodoopskrbni sustav pitke vode magistralnim cjevovodom s vodocrpilišta Belišće (rijeka Drava), no tek je pedeset jedno domaćinstvo, odnosno $60 \%$ kućanstava priključeno na vodoopskrbni sustav. Preostalo stanovništvo koristi pitku vodu iz vlastitih zdenaca. Zbrinjavanje kućne otpadne vode riješava se sabirnim jamama, dok se oborinska voda odvodi uličnim otvorenim oborinskim kanalima uz cestovne prometnice naselja. U cilju očuvanja podzemnih voda od onečišćenja, zdravlja ljudi te zaštite okoliša sa svim raznolikostima biljnog i životinjskog svijeta, u prosincu 2007. godine završena je izgradnja kanalizacijskog sustava s biljnim uređajem za pročišćavanje otpadnih voda.

Razlozi izgradnje biljnog uređaja bili su, između ostalih, i ekonomske prirode. Kako naselje nema većih vodotoka koji mogu preuzeti ulogu prijamnika/recipijenta, nije bilo mogućnosti izgradnje konvencionalnog uređaja za pročišćavanje otpadnih voda, a izgradnja kolektorskog cjevovoda do postojećeg uređaja za pročišćavanje otpadnih voda u gradu Belišću bila bi vrlo skupa. Bilo je potrebno postaviti više od $7 \mathrm{~km}$ cjevovoda, izgraditi crpne stanice koje bi premostile nepovoljnu konfiguraciju terena, a sve je iziskivalo sredstva daleko veće vrijednosti no što je izgradnja biljnog uređaja. Analizom isplativosti izgradnje biljnog uređaja utvrđena je prihvatljivost tog projekta jer su troškovi izgradnje biljnog uređaja (bez crpne stanice, prilazne ceste i kolektorske mreže) iznosili 
cca 730.000,00 kn, što je višestruko manje no što bi iznosili troškovi izgradnje kanalizacijskog cjevovoda do uređaja za pročišćavanje otpadnih voda u Belišću. Praćenjem troškova održavanja uređaja od 2008. godine do danas, ustanovljeno je da su oni izuzetno niski.Utrošak električne energije potrebne za rad crpne stanice je 58 kn/mjesečno, a nema potrošnje energije za pročišćavanje otpadne vode. lako je broj kućanstava priključenih na javni sustav odvodnje relativno mali i iznosi tek $42 \%$, pokrivaju se svi troškovi održavanja biljnog uređaja kao i potrošnje električne energije potrebne za rad crpne stanice. Broj korisnika sustava odvodnje povećavao se svake godine i unazad dvije godine više nije bilo potrebe iznova zasađivati nove biljke u bazenima, jer je u otpadnoj vodi dovoljno tvari potrebnih za njihov rast, razvoj i obnavljanje. Najveći trošak u održavanju biljnog uređaja predstavlja kasnojesenja košnja bazenskih biljaka te redovita sezonska mjesečna košnja nasipa.

Pročišćena otpadna voda iz biljnog uređaja izlijeva se u melioracijski kanal 3. reda «Panđenica l» i koristi se za natapanje poljoprivrednih površina. Do lipnja 2011. godine nije vršeno mjerenje dotoka otpadne vode na pročišćavanje, a procjena je da je u 2010. godinu pročišćeno $3760 \mathrm{~m}^{3}$ otpadne vode. Procjena je rađena temeljem utvrđene i izmjerene potrošnje pitke vode iz vodoopskrbnog sustava za 2010. godinu, koja je iznosila $7314 \mathrm{~m}^{3}$. Postavljanjem mjerača protoka na ulazu u crpnu stanicu omogućilo se kvalitetnije praćenje i utvrđivanje srednjeg dnevnog opterećenja. Izmjereni dotok otpadne vode na crpnu stanicu od lipnja 2011. godine do lipnja 2012. godine iznosi $3632 \mathrm{~m}^{3}$.

Izgradnjom biljnog uređaja nisu ugrožena staništa životinja, a kako se pročišćena voda izlijeva u melioracijski kanal, koji je do izgradnje biljnog uređaja bio uglavnom suh, životinjama je neprestano dostupna pitka voda. Puštanjem biljnog uređaja u rad i neprestanom opskrbom melioracijskog kanala pročišćenom otpadnom vodom utjecalo se na obogaćivanje biljnog i životinjskog svijeta. Biljni uređaj izgrađen je kao podpovršinski biljni uređaj u kojem voda protječe horizontalno u bazenima za filtriranje i poliranje, te horizontalno i vertikalno u bazenu za pročišćavanje.

Planirani broj stanovnika prigradskog naselja Vinogradci do 2015. godine iznosi tri stotine i prema tom planiranom broju izgrađen je uređaj za pročišćavanje otpadnih voda maksimalnog dnevnog opterećenja od 68 $\mathrm{m}^{3} /$ dan, odnosno srednjeg dnevnog operećenja od $45 \mathrm{~m}^{3} / \mathrm{dan}$. U 2010. godini srednje dnevno opterećenje procijenjeno je na $10,30 \mathrm{~m}^{3} / \mathrm{dan}$. Voda se u cijelom biljnom uređaju, što uključuje i taložnicu zadržava cca 4 dana [14]. Uređaj se sastoji od crpne stanice, taložnice, bazena za filtriranje, bazena za pročišćavanje bazena za poliranje otpadnih voda.

\subsection{Crpna stanica}

Crpnu stanicu za dovod vode u taložnicu ispred biljnog uređaja bilo je potrebno postaviti zbog premalog pada terena odnosno nepovoljnih topografskih karakteristika. Sama crpna stanica izvedena je kao podzemna građevina sastavljena od crpnog zdenca i zasunske komore. Opremljena je $s$ dvije crpke pojedinačnog kapaciteta $Q=4,00(2,00-10,00)$ l/s. Način rada crpki je jedna radna crpka + jedna crpka u pričuvi. Nadzor nad radom crpki prati se nadzorno upravljačkim sustavom i tijekom 24 sata dnevno isporučitelju vodne usluge (Kombel d.o.o. Belišće) osiguran je uvid u rad crpki.

\subsection{Taložnica}

Taložnica je smještena iza crpne stanice i prije bazena biljnog uređaja, te je ulazna građevina uređaja. Izvedena je kao ukopani armirano betonski objekt. Korisna zapremina iznosi $35 \mathrm{~m}^{3}$, što predstavlja količinu otpadne vode u poludnevnom zadržavanju [14]. U njoj se provodi mehaničko pročišćavanje otpadne vode i zadržavaju plivajuće masti i ulja na izvedenim uronjenim pregradama (slika 2). 

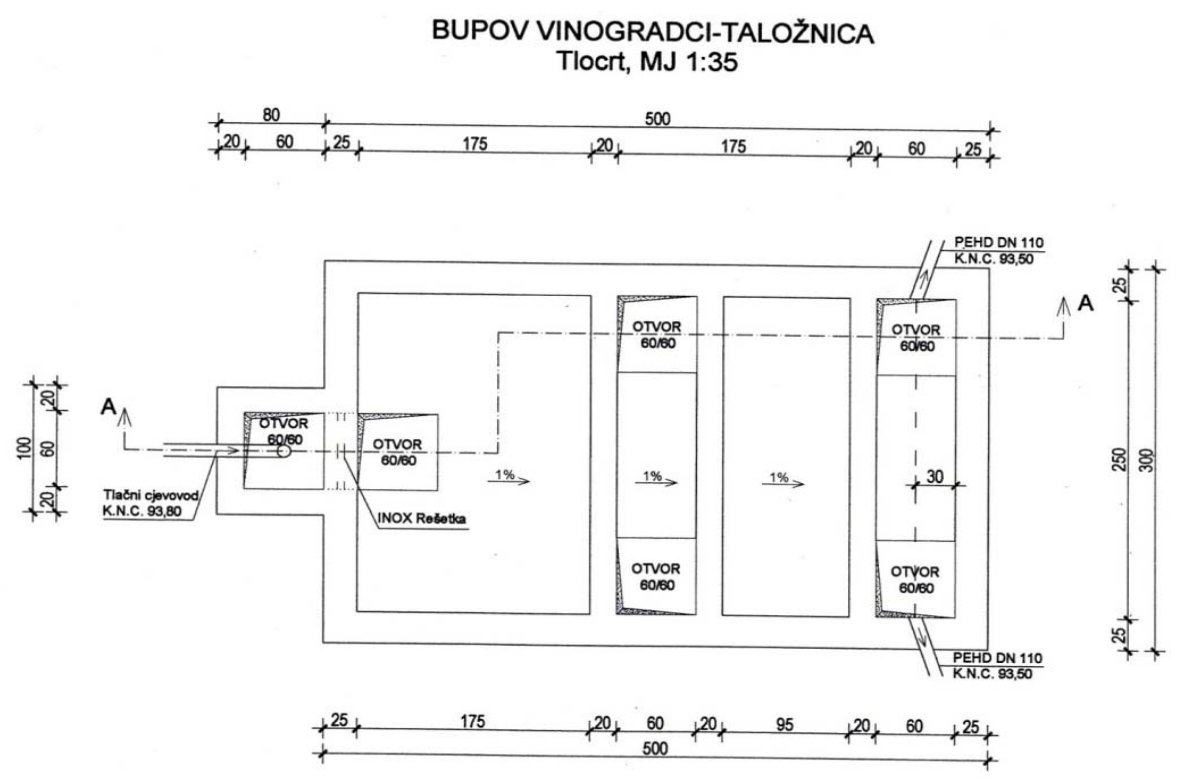

Slika 2 - Tlocrt taložnice biljnog uređaja Vinogradci [14]

\subsection{Bazen za filtriranje}

Bazen za filtriranje je prvi bazen u koji dotječe voda, u njemu se provodi filtriranje i zadržavanje preostalih suspendiranih tvari, te se na taj način štiti glavni sustav biljnog uređaja (slika 3). U ovom se bazenu odvija aerobno i anaerobno pročišćavanje, adsorpcija, apsorpcija i ugrađivanje hranjivih i otrovnih tvari u biomasu biljaka i mikroorganizama. Poprečni i uzdužni nagib dna bazena iznosi $1 \%$. Protok vode kroz sustav u ovom bazenu je horizontalan, a hidraulička provodljivost supstrata $0,10 \mathrm{~m} / \mathrm{s}$ [14].

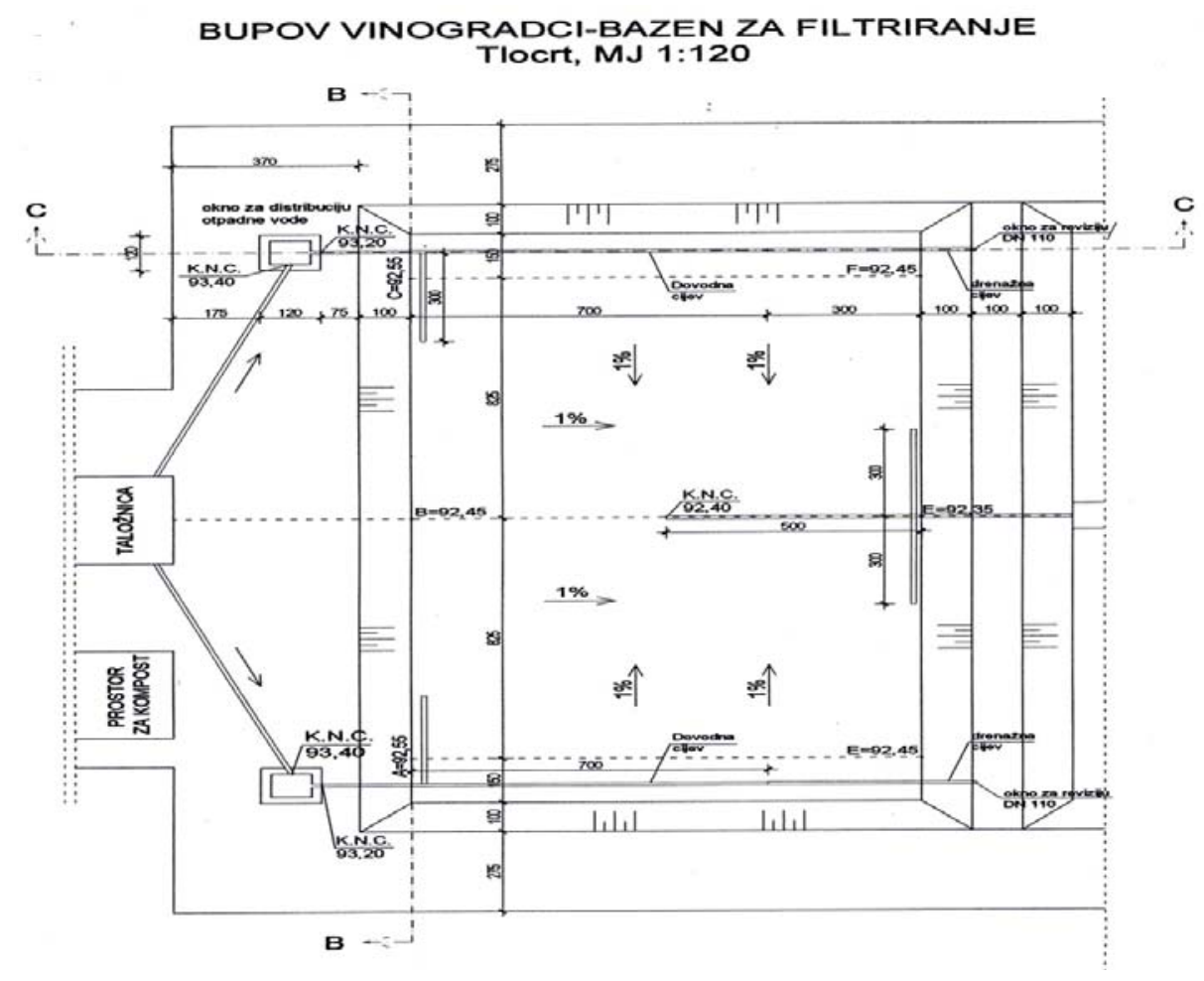

Slika 3 - Bazen za filtriranje

Šperac, M; Kaluđer, J; Šreng, Ž 
Dovod vode u ovaj bazen provodi se PEHD cijevima DN $110 \mathrm{~mm} / 4$ bara iz armirano betonskih okana smješenih rubno uz dužu stranicu bazena. Odvod vode u sljedeći bazen, bazen za pročišćavanje, provodi se perforiranom PEHD cijevi DN $110 \mathrm{~mm} / 4$ bara, a koja je položena sredinom bazena. Periodično čišćenje i pražnjenje bazena, u svrhu uklanjanja sakupljenog taloga, omogućeno je revizijskim oknima od cijevi promjera $100 \mathrm{~mm} / 4$ bara.

Slojevi u bazenu za filtriranje su šljunak $16 / 32 \mathrm{~mm}$ u debljini sloja $10 \mathrm{~cm}$, supstrat $4 / 16 \mathrm{~mm}$ u debljini sloja $60 \mathrm{~cm}$, zaštitni geotekstil debljine 1,4 mm, PEHD folija debljine $2 \mathrm{~mm}$, pijesak 0/4 mm u sloju debljine $10 \mathrm{~cm}$ i tlo zemljani isplanirani materijal.

\subsection{Bazen za pročišćavanje}

Bazen za pročišćavanje drugi je po redoslijedu bazen u kojeg dotječe voda, tlocrtno je podijeljen u dvije prostorno razdvojene uzdužne sekcije koje se izmjenično pune (slika 4). Razdijeljenost je postignuta izvedbom desetcentimetarskog nadvišenja kamenim materijalom u odnosu na površinu gornjeg šljunčanog sloja. Poprečni i uzdužni nagib dna bazena iznosi $1 \%$. U ovom se bazenu provodi filtriranje suspendiranih tvari, aerobno pročišćavanje, intenzivan unos kisika, ugradnja hranjivih tvari u biomasu biljaka i mikroorganizama te redukcija patogenih bakterija. Protok vode kroz sustav u ovom bazenu je verikalan i horizontalan, a hidraulička provodljivost supstrata $0,01 \mathrm{~m} / \mathrm{s}$ [14].

Dovod i odvod vode provodi se PEHD cijevima DN $110 \mathrm{~mm} / 4$ bara koje su obložene šljunkom veličine zrna 60 do $80 \mathrm{~mm}$.

Periodično čišćenje i pražnjenje i ovog bazena, u svrhu uklanjanja sakupljenog taloga, omogućeno je revizijskim oknima od cijevi promjera $100 \mathrm{~mm} / 4$ bara.

Slojevi u bazenu za pročišćavanje gotovo su jednaki slojevima bazena za filtriranje i različitost se odnosi samo na deblinu sloja supstrata, koji je u bazenu za pročišćavanje debljine $80 \mathrm{~cm}$.

BUPOV VINOGRADCI-BAZEN ZA PROCISCAVANJE Tlocrt, MJ 1:200

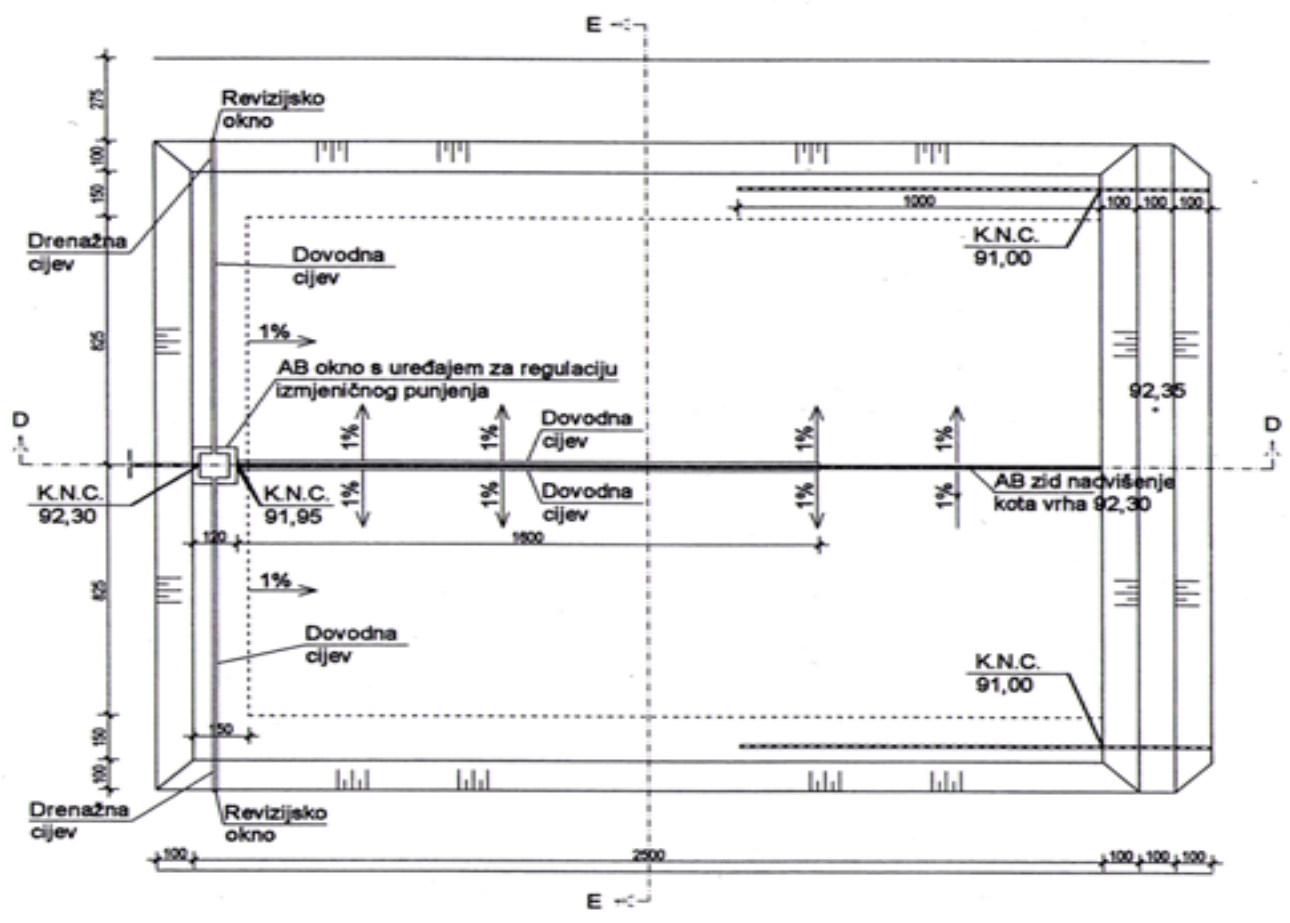

Slika 4 - Bazen za pročišćavanje 


\subsection{Bazen za poliranje}

Bazen za poliranje završni je bazen u tehnološkom nizu biljnog uređaja Vinogradci. Otpadna voda u njega se ravnomjerno izlijeva pomoću okana postavljenih u uglovima ulaznog dijela bazena (što je dobro vidljivo na slici 5). Okna su PVC cijevi promjera $400 \mathrm{~mm}$ i pri dnu su perforirana. Uzdužni i poprečni nagib dna ovog bazena izvodi se od okana i iznosi $1 \%$. U ovom se bazenu provodi konačno pročišćavanje otpadnih voda i kondicioniranje kisika, filtracija, adsorpcija, apsorpcija, ugradnja hranjivih i otrovnih tvari u biomasu biljaka i mikroorganizama te aerobno/anaerobno pročišćavanje. Protok vode kroz sustav u ovom bazenu je horizontalan, a hidraulična propusnost supstrata $0,01 \mathrm{~m} / \mathrm{s}$ [14]. Pražnjenje bazena vrši se perforiranom cijevi PEHD DN $110 \mathrm{~mm}$ NP 4 bara položenom u sredini bazena. Cijev dolazi do izlaznog okna opremljenog ventilom za regulaciju protoka, odakle se pročišćena voda odvodi kaskadama do melioracijskog kanala 3. reda Panđenica I, što je prikazano na slici 6. Debljina sloja supstrata $4 / 16 \mathrm{~mm}$ u bazenu za poliranje iznosi $50 \mathrm{~cm}$, dok su svi ostali slojevi jednaki za sve bazene.

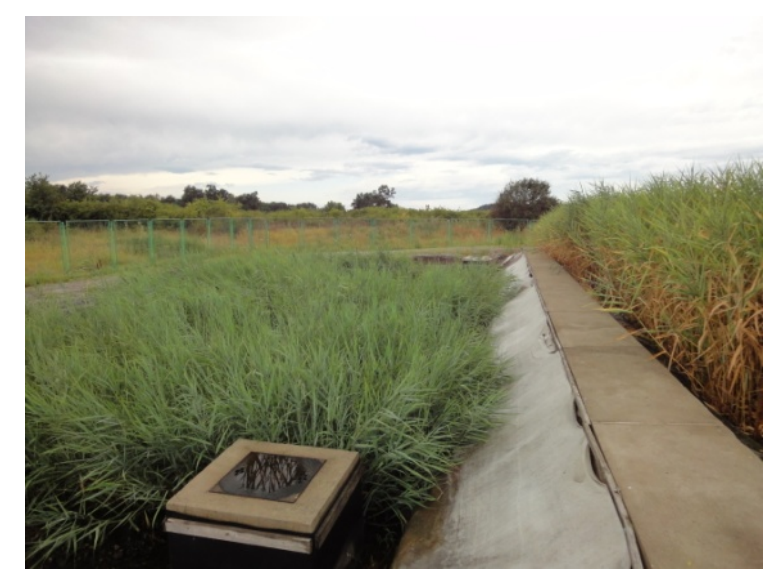

Slika 5 - Bazen za poliranje

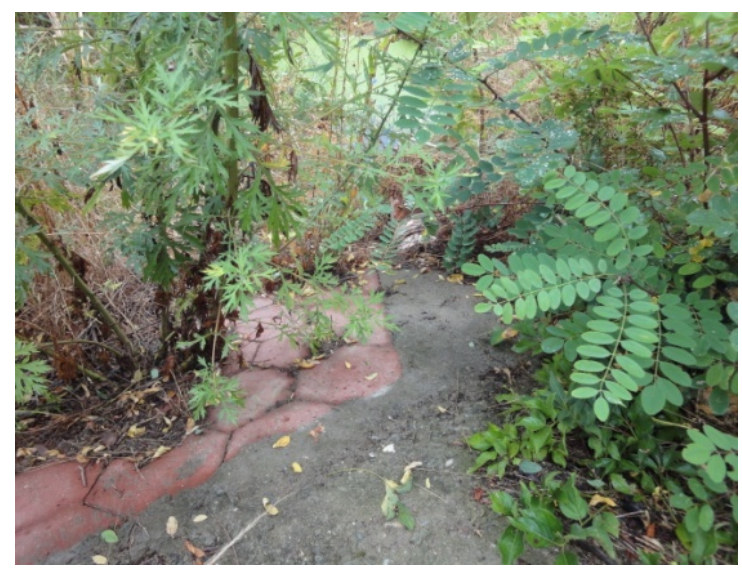

Slika 6 - Izljev u melioracijski kanal

\subsection{Monitoring biljnog uređaja Vinogradci}

Prema Pravilniku o graničnim vrijednostima opasnih i drugih tvari u otpadnim vodama (NN 94/08 i NN 87/10) isporučitelj vodne usluge (Kombel d.o.o. Belišće) obvezan je jednom godišnje vršiti analizu otpadnih voda, počevši od početka probnog rada uređaja 2008. godina. Mjesta uzorkovanja u toj su godini bila: crpna stanica, bazeni za filtriranje, pročišćavanje i poliranje, te izlaz iz biljnog uređaja. Rezultati uzorkovanja pokazuju visoku učinkovitost pročišćavanja i prikazani su u tablici 2. 
Tablica 2 - Rezultati analize otpadne vode u 2008. godini biljnog uređaja Vinogradci [15]

\begin{tabular}{|c|c|c|c|c|}
\hline $\begin{array}{c}\text { mjesto } \\
\text { uzorkovanja }\end{array}$ & parametri kvalitete & MDK & $\begin{array}{c}\text { nalaz } \\
10.10 .2008 .\end{array}$ & $\begin{array}{c}\text { nalaz } \\
17.11 .2008 .\end{array}$ \\
\hline \multirow{10}{*}{ Crpna stanica } & $\mathrm{pH}$ vrijednost & $6,5-9,5$ & 7,3 & 8,10 \\
\hline & temperatura & 40 & 17 & 15 \\
\hline & boja & & siva & sv.smeđa \\
\hline & miris & & na fekal. & na fekal. \\
\hline & otopljeni kisik & & 0,60 & 0,05 \\
\hline & suspendirana tvar(mg/l) & & 80,00 & 1,20 \\
\hline & $\mathrm{KPK}(\mathrm{mg} / \mathrm{l}) \mathrm{O} 2$ & 700 & 485 & 333 \\
\hline & BPK5 (mg/l) & 250 & 29 & 33,50 \\
\hline & ulja i masti & 100 & 36,50 & 4,50 \\
\hline & anionakt.detergent.(mgTBS/l) & 10 & 15,23 & 6,28 \\
\hline \multirow{10}{*}{$\begin{array}{l}\text { Izlaz bazena za } \\
\text { filtraciju }\end{array}$} & $\mathrm{pH}$ vrijednost & & 7,0 & 7,8 \\
\hline & temperatura & & 15 & 11 \\
\hline & boja & & bez & bez \\
\hline & miris & & bez & bez \\
\hline & otopljeni kisik & & 5,20 & 0,70 \\
\hline & suspendirana tvar(mg/l) & & 32,80 & 0 \\
\hline & $\mathrm{KPK}(\mathrm{mg} / \mathrm{l}) \mathrm{O} 2$ & & 73 & 95 \\
\hline & $\mathrm{BPK} 5$ (mg/l) & & 3,90 & 10,40 \\
\hline & ulja i masti & & 22,50 & 19 \\
\hline & anionakt.detergent.(mgTBS/l) & & 1,69 & 5,01 \\
\hline \multirow{10}{*}{$\begin{array}{l}\text { Izlaz bazena za } \\
\text { pročišćavanje }\end{array}$} & $\mathrm{pH}$ vrijednost & & 7 & 7,4 \\
\hline & temperatura & & 18 & 13 \\
\hline & boja & & bez & bez \\
\hline & miris & & bez & bez \\
\hline & otopljeni kisik & & 4,90 & 1,86 \\
\hline & suspendirana tvar(mg/l) & & 40,60 & 0 \\
\hline & $\mathrm{KPK}(\mathrm{mg} / \mathrm{l}) \mathrm{O} 2$ & & 34 & 10 \\
\hline & $\mathrm{BPK} 5(\mathrm{mg} / \mathrm{l})$ & & 3 & 8,6 \\
\hline & ulja i masti & & 4,50 & 0 \\
\hline & anionakt.detergent.(mgTBS/l) & & 1,39 & 0,86 \\
\hline \multirow{10}{*}{$\begin{array}{l}\text { Izlaz iz bazena } \\
\text { za poliranje }\end{array}$} & $\mathrm{pH}$ vrijednost & $6,5-9,0$ & 7,8 & 7,7 \\
\hline & temperatura & 30 & 16 & 11 \\
\hline & boja & bez & bez & bez \\
\hline & miris & bez & bez & bez \\
\hline & otopljeni kisik & & 3,80 & 4,82 \\
\hline & suspendirana tvar(mg/l) & 35 & 13 & 0 \\
\hline & $\mathrm{KPK}(\mathrm{mg} / \mathrm{l}) \mathrm{O} 2$ & 125 & 29 & 14 \\
\hline & $\mathrm{BPK} 5(\mathrm{mg} / \mathrm{l})$ & 25 & 0,80 & 2 \\
\hline & ulja i masti & 20 & 3,60 & 14 \\
\hline & anionakt.detergent.(mgTBS/l) & 10 & 2,11 & 1,35 \\
\hline
\end{tabular}

Tehnološkim projektom biljnog uređaja Vinogradci bile su utvrđene vrijednosti pokazatelja koji trebaju zadovoljiti zakonom tražene parametre za III kategoriju prijamnika (melioracijski kanal) prikazanim u tablici 3. 
Tablica 3 - Tehnološkim projektom predviđene vrijednosti parametara biljnog uređaja Vinogradci [14]

\begin{tabular}{|l|l|l|}
\hline \multirow{2}{*}{ Pokazatelj } & Koncentracija (mg/l) \\
\cline { 2 - 3 } & Ulaz (x) & Izlaz \\
\hline BPK5 & $300-400$ & 40 \\
\hline KPK & $600-800$ & 150 \\
\hline Ukupna suspendirana tvar & $350-470$ & 60 \\
\hline Ukupni fosfor & $12,5-16,7$ & 2 \\
\hline Ukupni dušik & $55-73$ & 15 \\
\hline
\end{tabular}

Rezultati uzorkovanja i ispitivanja sastava otpadne vode na uzorcima uzimanim dana 28.03.2012. godine prikazani su u tablici br. 4. i ukazuju na dobru kakvoću otpadne vode i smanjene amonijeve ione, ukupni dušik i organske tvari - KPK i BPK5.

Tablica 4 - Rezultati analize otpadne vode u 2012.godini biljnog uređaja Vinogradci [16]

\begin{tabular}{|c|c|c|c|}
\hline parametri kvalitete & metoda & $\begin{array}{c}\text { crpna stanica - } \\
\text { ulaz }\end{array}$ & $\begin{array}{c}\text { crpna stanica - } \\
\text { izlaz }\end{array}$ \\
\hline Temperatura zraka ${ }^{\circ} \mathrm{C}$ & & 14 & 14 \\
\hline Temperatura vode ${ }^{\circ} \mathrm{C}$ & & 13 & 10 \\
\hline $\mathrm{pH} 6,5-9,5$ & HRN ISO 10523:1998 & 7,88 & 7,33 \\
\hline $\begin{array}{r}\text { Taloženje po IMHOFF - } 10^{\prime}(\mathrm{ml} / /) \\
-30^{\prime}(\mathrm{ml} / /) \\
-60^{\prime}(\mathrm{ml} / /) \\
-120^{\prime}(\mathrm{ml} / /)\end{array}$ & sm & $\begin{array}{l}0,2 \\
0,2 \\
0,2 \\
0,2\end{array}$ & $\begin{array}{l}0,1 \\
0,1 \\
0,1 \\
0,1\end{array}$ \\
\hline Ukupna suspendirana tvar (mg/l) & HRN ISO 11923:1998 & 12 & 6 \\
\hline Ukupna tvar sušena na $105^{\circ} \mathrm{C}(\mathrm{mg} / \mathrm{l})$ & & 1104 & 1059 \\
\hline Ukupna tvar žarena na $600^{\circ} \mathrm{C}(\mathrm{mg} / \mathrm{l})$ & & 657 & 728 \\
\hline Gubitak žarenjem & & 447 & 331 \\
\hline $\mathrm{KPK}\left(\mathrm{mgO}_{2} / \mathrm{l}\right) \quad 700$ & HRN EN 1899-1:2004 & 574 & 52 \\
\hline $\mathrm{BPK}_{5}\left(\mathrm{mgO}_{2} / \mathrm{l}\right) \quad 250$ & HRN EN 1899-1 & 339 & 26 \\
\hline Ukupna ulja i masti (mg/l) 100 & $\mathrm{sm}$ & 6,1 & 1,3 \\
\hline Otopljeni $\mathrm{O}_{2}(\mathrm{mg} / \mathrm{l})$ & & 0,05 & 7,24 \\
\hline Detergenti anionski $(\mathrm{mg} / \mathrm{l}) \quad \mathbf{1 0}$ & HRN EN 903:2002 & 6,53 & 0,38 \\
\hline Mineralna ulja $(\mathrm{mg} / \mathrm{l}) \quad 30$ & $\mathrm{sm}$ & 0,29 & 0,02 \\
\hline Amonijak (mg/l) & HRN ISO 5664:1998 & 76,578 & 24,558 \\
\hline Nitrati $(\mathrm{mg} / \mathrm{l})$ & HRN ISO 7890-1:1998 & 2,35 & 27,46 \\
\hline Nitriti $(\mathrm{mg} / \mathrm{ll}) \quad 10$ & HRN EN 26777:1998 & $<0,002$ & $<0,002$ \\
\hline Kjeldahlov N (mg/l) & & 117,00 & 32,00 \\
\hline Ukupni N (mg/l) & HRN ISO 5663:2001+NO2 & 119,35 & 59,46 \\
\hline Ukupan P $(\mathrm{mg} / \mathrm{l})$ & HRN ISO 6878:2001 & 2,2190 & 11,3420 \\
\hline
\end{tabular}

Analizom provedenih ispitivanja otpadnih voda za 2008. do 2012. godina utvrđeno je da su zadovoljeni tehnološkim projektom tražene vrijednosti, čime je dokazana visoka učinkovitost pročišćavanja.

\section{Zaključak}

Prije ispuštanja u vodne sustave ili prije moguće ponovne upotrebe otpadne vode se moraju pročistiti. Postupci pročišćavanja otpadnih voda naglo se razvijaju u cijelom svijetu. Postupci pročišćavanja se mogu podijeliti na konvencionalne metode pročišćavanja (za koje su potrebna visoka financijska ulaganja) i nekonvencionalne metode pročišćavanja otpadnih voda - biljni uređaji.

Prednosti izgradnje biljnih uređaja: niski troškovi izgradnje, niski troškovi rada, djeluju kao prirodni - zeleni proces, dobro se uklapaju u okoliš i osiguravaju život na staništu, osiguravaju pročišćavanje oborinskih voda za 
manja naselja, mogu biti izgrađeni od lokalnih materijala i saditi se autohtonim biljkama. Nedostaci biljnih uređaja u odnosu na konvencionalne: veća potreba za zemljišnom površinom, povoljan pad terena, veća osjetljivost prema anaerobnim stanjima.

Biljni uređaji za pročišćavanje otpadnih voda prihvatljiv su i ekonomski opravdan način zaštite voda i prirode uopće, jer nemaju velike utroške energije i koriste procese koji se i inače događaju u prirodi, čime podržavaju održivi razvitak. Nadalje, ekološki su prihvatljivi jer biljke obrađuju otpadne vode, svojom se izvedbom uklapaju u prirodan okoliš i često postaju staništa životinjama.

\section{Literatura}

[1] Pravilnik o graničnim vrijednostima emisija otpadnih voda NN 87/10, članak 2q), članak 7 stavak 12, članak 8 , članak 10

[2] Bonacci, O. Ekohidrologija vodnih resursa i otvorenih vodotoka, Građevinsko-Arhitektonski fakultet Sveučilišta u Splitu, 2003.

[3] Stottmeister, U. at all : Effects of plants and microorganisms in constructed wetlands for wastewater treatment, Biotechnology Advances, Volume 22, Issues 1-2, December 2003, Pages 93-117

[4] Vymazal, J.: The use of sub-surface constructed wetlands for wastewater treatment in the Czech Republic: 10 years experience. Ecological Engineering, 2002; 18 (5): 633-646

[5] Ružinski, N., Vučinić-Anić, A., Stilinović, B., Andročec, V., Juretić, H. Biljni uređaji - mogućnosti ograničenja u obradi otpadnih voda, Gospodarstvo i okoliš 67/2004

[6] Lesage, E.Rousseau, D.P.L.,Meers, E., Tack, F.M.G., De Pauw, N.: Accumulation of metals in a horizontal subsurface flow constructed wetland treating domestic wastewater in Flanders, Belgium. Science of The Total Environment, 2007.; 380 (1-3): 102-115

[7] Solano,M.L., Soriano, P., Ciria, M.P.: Constructed Wetlands as a Sustainable Solution for Wastewater Treatment in Small Villages. Biosystem Engineering, 2004.,87(1):109-118

[8] Sawaittayothin, V., Polprasert, C.: Nitrogen mass balance and microbial analyses of consrusted wetlands treating municipal landfill leachate. Bioresource Technology, 2007., 98(3): 565-570

[9] Huertas, E., Folch, M., Salgot, M., Gonzalvo, I., Passarell, C.: Constructed wetlands effluent for streamflow augmentation in the Besos River ( Spain). Desalination, 2006., 188(1-3):141-147

[10] Davies, L.C.,Carias, C.C., Novais, J.M., Martins-Dias, S.: Phytoremediation of textile effluents containing azo dye by using Phragmites australis in a vertical flow intermitent feeding Constructed wetland. Ecological Engineering, 2005., 25(5) 594-605

[11] Ružinski, N.; Anić Vučinić, A.: Obrada otpadnih voda biljnim uređajima, Hrvatska sveučilišna naklada, Zagreb 2010.

[12] Marinac-Pupavac, S., Shalabi, M., Stilinović, B. Pročišćavanje otpadnih voda u turizmu biljnim pročistačima, bib.irb.hr/datoteka/242984.prociscavanje_otpadnih_voda_u_turizmu.doc ( 20.11.2013.)

[13] Lawrence K: Environmental Bioengineering: Idris A at all: Wetlads for wastewater treatments (317-350) Handbook of Environmental Engineering, 2010.

[14] Tehnološki projekt biljnog uređaja za pročišćavanje otpadnih voda Vinogradaca, 2001. godina, izrađen u BiEco d.o.o. Rijeka

[15] Analize ispitivanja otpadnih voda biljnog uređajaVinogradci dostavljene od strane ovlaštenog laboratorija Belišća d.d., ovlaštenje izdano 16.04.2004. godine, Klasa: VP/I-034-01/3-01/0008, Ur.br.: 525-10/2-15-04005/006

[16] Analize ispitivanja otpadnih voda crpne stanice biljnog uređajaVinogradci dostavljene od strane laboratorija Vodovod Osijek d.o.o., PJ Kanalizacija, RJ EKO- laboratorij, datum uzimanja uzoraka 28.03.2012. godine. 